\title{
Telaah Praksis Pendidikan Agama Islam di Sekolah Dalam Pembentukan Karakter Siswa
}

\author{
Moch Iqbal \\ IAIN Bengkulu \\ moch_iqbal@iainbengkulu.ac.id
}

\begin{abstract}
This paper examines the strategic role of religious education in the national education system. In accordance with the mandate of UU Sisdiknas no 20/2003 that religious education is part of national education. Moreover, the issue of character education is getting stronger, increasingly placing religious education, in this case Islamic Education (IE) as the spearhead in guarding the implementation of character education. By using literature study, the results of this study were obtained, that the implementation of IE needs to be improved in order to produce students with character. Some obstacles in the implementation of Islamic religious education, making the PAI has not been able to produce students of character as much as expected by all parties. There are two dominant causes in the implementation of IE that are less than the maximum. First, IE puts more emphasis on the mastery of texts contained in textbooks and outer cognitive only (cognitive domain), whereas the substance of the cultivation of religious values just disappears as the cognitive knowledge accumulates. Second, the doctrinal learning process must be accepted, without growing the students' critical reason.
\end{abstract}

Keywords: Praxis, Islamic Education, Character Education

\begin{abstract}
Abstrak : Paper ini mengkaji peran strategis pendidikan agama dalam sistem pendidikan nasional. Sesuai dengan amanat UU Sisdiknas no 20/2003 bahwa pendidikan agama adalah bagian dari pendidikan nasional. Terlebih lagi, issu pendidikan karakter semakin menguat, semakin menempatkan pendidikan agama, dalam hal ini Pendidikan Agama Islam (PAI) sebagai ujung tombak dalam mengawal pelaksanaan pendidikan karakter. Dengan menggunakan studi pustaka, hasil kajian ini didapatkan, bahwa pelaksanaan PAI perlu diperbaiki agar menghasilkan siswa yang berkarakter. Beberapa kendala dalam pelaksanaan pendikan agama islam, menjadikan PAI belum bisa menghasilkan siswa yang berkarakter sebagaimana yang banyak diharapkan oleh semua pihak. Ada dua sebab yang dominan dalam implementasi PAI yang kurang maksimal. Pertama, PAI lebih menekankan pada pada penguasaan teks-teks yang terdapat dalam buku pengajaran dan hapalan kulit luarnya saja (ranah kognitif), sedangkan substansinya berupa penanaman nilai-nilai agama hilang begitu saja seiring dengan bertumpuknya pengetahuan kognitif. Kedua, proses pembelajaran yang doktrinal yang harus diterima, tanpa menumbuhkan nalar kritis siswa.

Kata kunci: Praksis, Pendidikan Agama Islam, Pendidikan karakter
\end{abstract}

\section{Pendahuluan}

Sejatinya pendidikan agama dalam sistem pendidikan nasional tidak bisa terpisahkan. Undang-undang No. 20 tahun 2003 secara tegas menyatakan bahwa pendidikan agama merupakan bagian yang tak terpisahkan dari sistem pendidikan nasional. Setiap lembaga pendidikan mulai dari tingkat dasar sampai perguruan tinggi, mengharuskan pendidikan agama berada di dalamnya. Hal ini terkait dengan filosofi pendidikan nasional yang menjadikan Pancasila sebagai dasar yang melandasinya. Sila pertama 'Ketuhanan yang Maha Esa', mewajibkan 
agama selalu terlibat dalam setiap kegiatan berbangsa dan bernegara, terlebih lagi dalam kegiatan pendidikan nasional, sebagai salah satu pilar pembentukan manusia seutuhnya (nation and caracter building).

Pasal 37 ayat (1) menjelaskan bahwa pendidikan agama dimaksudkan untuk membentuk peserta didik menjadi manusia yang beriman dan bertaqwa, kepada Tuhan Yang Maha Esa serta berakhlak mulia (UU No 20/2003). Maka memasukkan pendidikan agama dari mulai tingkat pendidikan dasar, menengah hingga perguruan tinggi, diharapkan peserta didik terbentuk karakternya sesuai dengan nilai-nilai yang terkandung dalam agama yang ada di Indonesia.

Prakteknya, pendidikan agama masih banyak menyimpan persoalan terkait amanat yang dibebankan kepada pendidikan agama. Seperti yang disinyalir oleh Munir Mulkhan (2004), para peserta didik hanya diarahkan pada penguasaan materi agama, yang hanya menghasilkan kesalahan ritual, namun minus kesalehan sosial.

Sebagai implikasinya muncul berbagai persoalan sosial, eksklusivisme, fanatisme yang berlebihan pada agama, intoleransi, ketidakpedulian sosial dan berbagai persoalan sosial lainnya. Kasus kerusuhan Tasikmalaya, Situbondo (1997); Medan, Jakarta, Solo, Ketapang, dan Kupang (1998); Bali (1999), Ambon, Maluku Utara (1999/2000; 2003/2004), Mataram (2000), Kalimantan (2004), Jakarta (2005), dan Poso (2003-2006) merupakan contoh aktual yang masih segar dalam ingatan (Suaedi, 2012).

Catatan The Wahid Institut (2012), Laporan the Wahid Institute menyuguhkan. Dibanding 2010, tindakan pelanggaran tahun 2011 meningkat 18 persen menjadi 93 kasus. Tahun 2010 terjadi 64 kasus. Begitupun tin- dakan intoleransi yang naik 16 persen menjadi 184 kasus, atau rata-rata 15 kasus setiap bulannya di tahun 2011. Tahun 2010, jumlahnya 134 kasus. Tahun 2012, sepertinya pelanggaran belum turun. Pada kategori pelanggaran, data-data korban terbanyak adalah kelompok minoritas keagamaan dan keyakinan: Jemaat Ahmadiyah Indonesia (JAI) dengan 47 kasus (50 persen). Disusul Jemaat GKI Yasmin 13 kasus (14 persen), jemaat gereja lain 12 kasus (13 persen), kelompok terduga sesat 8 kasus ( 9 persen), kelompok Syiah 2 kasus ( 2 persen), Millah Abraham 4 kasus ( 4 persen), AKI 2 kasus ( 2 persen), jemaah masjid, Nurul Amal, Bedatuan, Aliran Islam Suci, Padepokan Padange Ati, masing- masing satu kasus (1 persen). Terbaru, adalah kekerasan dan ujaran kebencian selama hajatan Pilpres dan pileg 2019, dimana simbol-simbol agama muncul cukup dominan di permukaan.

Realitas yang semacam itu, menjadi suatu tantangan dan memaksa khususnya para intelektual agama dan orang-orang yang bergerak dalam pendidikan agama (termasuk mubaligh dan guru agama) untuk mengkaji dan menelaah berbagai aksi-aksi kekerasan tersebut dan konflik yang berbasis pada keyakinan agama melalui seminar- seminar, forum kajian lintas agama dan budaya 
yang mengangkat tema isu-isu pluralisme dan multikulturalisme. Namun, dirasakan semangat dan intensitas diskusi dan kajian tersebut agaknya masih banyak yang dilakukan atas dasar kepentingan sosiologis, politis atau sejenisnya. Belum dibarengi dengan perubahan paradigma dan tata pikir keagamaan yang lebih mendasar di kalangan para intelektual agama (Suyatno, 2013).

\section{Pendidikan Agama Dalam Undang Undang Sisdiknas}

Undang-undang No. 20 tahun 2003 secara tegas menyatakan bahwa pendidikan agama merupakan bagian yang tak terpisahkan dari sistem pendidikan nasional. Setiap lembaga pendidikan mulai dari tingkat dasar sampai perguruan tinggi wajib memasukkan pendidikan agama sebagai muatan kurikulum. Pasal 37 ayat (1) menjelaskan bahwa pendidikan agama dimaksudkan untuk membentuk peserta didik menjadi manusia yang beriman dan bertaqwa kepada Tuhan Yang Maha Esa serta berakhlak mulia.

Disamping tujuan bertaqwa kepada Tuhan Yang Maha Esa, diharapkan dengan masuknya pendidikan agama di sekolah mampu memperkuat karakter dan moralitas siswa. Moralitas yang tinggi diyakini menjadi sumber dan modal utama dalam membangun peradaban bangsa yang besar seperti Indonesia. Dengan potensi wilayah yang membentang, tidak kurang dari 17 ribu pulau dan kekayaan demografi yang mencapai tidak kurang dari 250 juta, diperlukan kekuatan moral-spiritual dan ilmu pengetahuan yang memadahi untuk mengelolanya.

Sekolah sebagai lembaga strategis dalam mengelola sumberdaya manusia adalah tempat yang paling tepat dalam mengemban amanat tersebut. Namun dalam pelaksanaanya, pendidikan agama, terutama Pendidikan Agama Islam (PAI) mengalami beberapa hambatan dalam mencapai tujuan nation and caracter building. Bila diperhatikan lebih lanjut paling tidak ada dua faktor, yaitu faktor internal dan faktor eksternal.

Faktor Internal, menyangkut masalah sarana dan prasarana terbatas, kurikulum kurang mendukung, kurangnya tenaga pendidik. Sedangkan faktor eksternal, menyangkut maslah lingkungan sosial sekolah (misalnya di kawasan industri yang kurang kondusif untuk belajar), perkembangan teknologi informasi yang tidak diiringi kesadaran literasi dengan baik, sehingga melunturnya nilai-nilai local wisdom.

Kerumitan lain juga muncul. Satu sisi pendidikan agama melekat dalam pendidikan nasional, sisi lain menjalankan pendidikan dengan sepenuhnya sesuai dengan agama selalu dicurigai dan bahkan tidak jarang diintimidasi. Maka pendidikan agama harus mampu menempatkan diri diantara agama-agama lainnya di Indonesia juga menyangkut kepentingan negara yang lebih besar. 
Lebih komplek lagi, pendidikan agama sendiri tidaklah homogen. Paling tidak bila dilihat dari perspektif praksis pendidikan agama Islam ada tiga katagori: Pertama, pendidikan agama integratif, yaitu pendidikan agama islam yang bisa terintegrasi dengan kurikulum pendidikan nasional. Pendidikan agama islam (PAI) bisa dipadukan dengan semua mata pelajaran di sekolah. Misalnya Matematika, Ilmu pengetahuan Alam (IPA) dan semua mata pelajaran lainnya. Pandangan seperti ini banyak dianut oleh para ahli pendidikan agama, karena pada dasarnya agama dan ilmu pengetahuan tidak dapat dipisahkan. Secara sederhana, bahwa PAI tidak bertentangan dengan sistem pendidikan nasional sebagaimana yang tertera dalam UU Sisdiknas no 20/2003. Dalam prakteknya katagori ini mulai banyak dipergunakan dan dikembangkan diberbagai lembaga pendidikan. Misalnya sekolah-sekolah Modern semacam SMA al Azhar Jakarta jaringan MAN Insan Cendikia, jaringan sekolah Islam terpadu dan sekolahsekolah kecil yang banyak bertebaran diseluruh pelosok nusantara.

Kedua, pendidikan agama separatif, yaitu pandangan yang memisahkan antara pendidikan agama dan pendidikan nasional. Praktek pendidikan yang separatif ini banyak dipraktekkkan di lembaga-lembaga pendidikan keagamaan semacam pesantren salaf yang mengkhususkan pada kajian-kajian keagamaan semata. Pada masa lalu praktek pendidikan semacam ini, yaitu yang memfokuskan pendidikan agama dipelopori oleh Nizam al-Mulk menciptakan sistem pendidikan yang dikenal sebagai "Nizamiyah" yang fokus pada studi keagamaan dan mengorbankan kebebasan sains (DW Indonesia, 2017). Untuk pertama kalinya dalam sejarah Islam, pendidikan agama terinstitusionalisasi dan dianggap menawarkan peluang karir yang lebih menjanjikan ketimbang sains dan studi hukum Islam. Model lembaga pendidikan semacam ini secara kwantitatif tidak banyak dan masih terbatas.

Ketiga, Pendidikan Agama akomodatif, pandangan ini sebagai jalan tengah antara pandangan integrasi dan pandangan separasi, yaitu dengan memasukkan bagaian-bagaian agama yang bisa diintegrasikan dengan mata pelajaran nasional. Misalnya nilai-nilai toleransi, kewajiban menuntut ilmu, kewajiban menjaga kebersihan dan sebagainya.

\section{Metode Penelitian}

Penulisan ini menggunakan kajian pustaka dengan cara mengutip pendapat dari tulisan yang telah dibaca, kemudian ditelaah dan dianalisis sesuai dengan kemampuan penulis yang bergiat di dunia pendidikan. Untuk pengumpulan data pada makalah ini digunakan metode pengumpulan data literer, yakni dengan terlebih dahulu menelusuri buku - buku yang ada 
relevansinya dengan masalah - masalah yang dibahas dan melalui jaringan internet untuk dikaji guna mencari landasan upaya pemecahan persoalan

\section{Praksis Pendidikan Agama}

Pendidikan agama Islam yang dimasukkan dalam kurikulum pendidikan umum mulai dari tingkat dasar sampai perguruan tinggi, merupakan bagian dari pendidikan Islam yang sarat dengan nilai-nilai moral dan spiritual. Pendidikan Islam mempunyai misi esensial untuk membangun karakter muslim yang memahami ajaran agamanya serta mempunyai kesadaran imani yang diwujudkan ke dalam sikap dan perilaku sehari- hari sebagai bentuk pengamalan ajaran agama. Menurut Syed Muhammad Naquib Al-Attas, hasil yang ingin dicapai dari pendidikan Islam adalah menciptakan manusia beradab dalam pengertian yang menyeluruh meliputi kehidupan spiritual dan material (Wan Mohd. Nor Wan Daud, hal 174, 1989). Begitu juga menurut al-Abrasyi, mencapai suatu akhlak yang sempurna (fadhilab) adalah tujuan utama pendidikan Islam.

Namun faktanya berbicara lain, pendidikan agama Islam (PAI), secara umum belum mampu berkontribusi positif terhadap peningkatan moralitas dan sikap toleransi khususnya di kalangan peserta didik. Hal ini sangat terkait dengan proses implementasinya di lapangan. Dalam praksisnya peserta didik selalu diarahkan pada penguasaan teks-teks yang terdapat dalam buku pengajaran, mereka selalu dihadapkan pada pertanyaan dan hapalan kulit luarnya saja (ranah kognitif), sedangkan substansinya berupa penanaman nilainilai agama hilang begitu saja seiring dengan bertumpuknya pengetahuan kognitif mata pelajaran yang ada di sekolah (Sutrisno, hal 85 2011).

Pendidikan Agama Islam yang diajarkan selama ini pada lembagalembaga pendidikan umum mulai dari tingkat SD sampai perguruan tinggi lebih bersifat transfer of knowledge, lebih menekankan kepada pencapaian penguasaan ilmu-ilmu agama. Fragmentasi materi dan terisolasinya atau kurang terkaitnya dengan konteks yang dihadapi dalam kehidupan sehari-hari yang menyebabkan peserta didik kurang menghayati nilai-nilai agama sebagai nilai yang hidup dalam keseharian.

Konsekuensinya pendidikan agama Islam yang diajarkan menjadi kurang bermakna, kebanyakan peserta didik meningkat pengetahuannya tentang agama, akan tetapi penghayatan dan pengamalan terhadap nilai-nilai agama terutama yang bersentuhan dengan nilai-nilai humanis dalam bentuk kepedulian sosial misalnya, kurang teraktualisasi dalam kehidupan sehari- hari (Munir Mulkhan, 2014). Bahkan, tidak jarang pendidikan agama yang membawa kepada kecenderungan sikap dan perilaku peserta didik yang eksklusif dan fanatiks. Sikap eksklusif dan fanatiks inilah yang pada gilirannya melahirkan sikap intoleranasi terhadap perbedaan agama dan sulit menerima perbedaan etnis dan budaya. 
Kurang berkembangnya konsep bumanisme atau pendidikan agama yang berbasis problem sosial menurut istilah Sutrisno (2011), dalam sistem pendidikan agama Islam karena dalam praksisnya pendidikan agama lebih berorientasi pada konsepsi manusia sebagai "'abdullah" yang lebih menekankan pada pemahaman keagamaan yang dimaknai sebagai ritual dalam bentuk ibadah mabdhah yang hanya melahirkan manusia-manusia yang "saleh" secara individual namun tidak secara sosial (Abdul Munir Mulkhan, 2005).

Salah satu aspek humanisme yang sekarang ramai dibicarakan dan menjadi isu-isu penting dalam wacana perdebatan adalah mengenai isu toleransi. Sebagaimana diketahui kondisi bangsa Indonesia yang ditakdirkan oleh Tuhan memiliki keragaman etnik, budaya dan agama. Keberagaman tersebut belakangan seringkali menyulut prilaku intoleran. penyelenggaraan pendidikan yang banyak dilatarbelakangi oleh primordialisme. Misalnya pendirian lembaga pendidikan berdasar latar belakang agama, daerah, perorangan maupun kelompok, bila tidak dikelola dengan nilai-nilai multikultural akan berpotensi menyemai benih-benih intoleran.

Pendidikan multikultural di Indonesia dapat dilaksanakan secara fleksibel dengan mengutamakan prinsip-prinsip dasar multikultural. Apapun dan bagaimanapun bentuk dan model pendidikan multikultural, mestinya tidak dapat lepas dari tujuan umum pendidikan multikultural, yaitu : (1) Mengembangkan pemahaman yang mendasar tentang proses menciptakan sistem dan menyediakan pelayan pendidikan yang setara. (2) Menghubungkan kurikulum dengan karakter guru, pedagogi, iklim kelas, budaya sekolah dan konteks lingkungan sekolah guna membangun suatu visi "lingkungan sekolah yang setara"

Prinsip fleksibilitas pendidikan multikultural juga disarankan oleh Gay (2002) sebagaimana dikutip Zamroni ( 2011 : 150 ), dikatakan bahwa amat keliru kalau melaksanakan pendidikan multikultural harus dalam bentuk mata pelajaran yang terpisah atau monolitik. Sebaliknya, dia mengusulkan agar pendidikan multikultural diperlakukan sebagai pendekatan untuk memajukan pendidikan secara utuh dan menyeluruh. Pendidikan multikultural juga dapat diberlakukan sebagai alat bantu untuk menjadikan warga masyarakat lebih memiliki toleran, bersifat inklusif, dan memiliki jiwa kesetaraan dalam hidup bermasyarakat, serta senantiasa berpendirian suatu masyarakat secara keseluruhan akan lebih baik, manakala siapa saja warga masyarakat memberikan kontribusi sesuai dengan kemampuan dan kesempatan yang dimiliki bagi masyarakat sebagai keutuhan.

Zamroni (2011), pendidikan multikultural diusulkan untuk dapat dijadikan instrument rekayasa sosial lewat pendidikan formal, artinya institusi sekolah harus berperan dalam menanamkan kesadaran hidup dalam masyarakat multikultural dan mengembangkan sikap tenggang rasa dan toleransi untuk 
mewujudkan kebutuhan serta kemampuan bekerjasama dengan segala perbedaan yang ada.

Sekolah harus dipandang sebagai suatu masyarakat, masyarakat kecil; artinya, apa yang ada di masyarakat harus ada pula di sekolah. Perspektif sekolah sebagai suatu masyarakat kecil ini memiliki implikasi bahwa siswa dipandang sebagai suatu individu yang memiliki karakteristik yang terwujud dalam bakat dan minat serta aspirasi yang menjadi hak siswa.

Pada level sekolah, dengan adanya berbagai perbedaan yang dimiliki masing-masing individu, maka sekolah harus memperhatikan: a) setiap siswa memiliki kebutuhan perkembangan yang berbeda-beda, termasuk kebutuhan personal dan sosial, b) kebutuhan vokasi dan karier, c) kebutuhan psikologi dan perkembangan moral spiritual.

Pada level masyarakat, yang perlu dipenuhi kebutuhannya adalah mencakup : a) kebutuhan akademik, b) kebutuhan psikologis, c) kebutuhan kebersamaan, dan d) kebutuhan rasa aman. Pendidikan harus dapat memenuhi kebutuhan tersebut. Sekolah harus dapat dijadikan tempat yang aman, memiliki suasana kekerabatan dan juga terdapat semangat saling dukung mendukung. Berkaitan dengan itu, maka prosses pembelajaran diarahkan pada pengembangan individu secara utuh yang mencakup intelektual, sosial, dan moral spiritual. Tekanan dan dorongan siswa untuk bekerja keras tidak hanya bersifat ekstrinsik, bahkan lebih dari itu harus ditekankan pada penggunaan instrinsik motivation.

Dari perspektif hasil pembelajaran, pendidikan multikultural memiliki tiga sasaran yang dikembangkan pada diri setiap siswa; Pertama, pengembangan identitas kultural yakni merupakan kompetensi yang dimiliki siswa untuk mengidentifikasi dirinya dengan suatu etnis tertentu. Kompetensi ini mencakup pengetahuan, pemahaman dan kesadaran akan kelompok etnis dan menimbulkan kebanggaan serta percaya diri sebagai warga kelompok etnis tertentu.

Kedua, hubungan interpersonal. Yakni, kompetensi untuk melakukan hubungan dengan kelompok etnis lain, dengan senatiasa mendasarkan pada persamaan dan kesetaraan, serta menjauhi sifat syakwasangka dan stereotip. Ketiga, memberdayakan diri sendiri. Yakni suatu kemampuan untuk mengembangkan secara terus menerus apa yang dimiliki berkaitan dengan kehidupan multikultural.

Secara detail, kompetensi kultural mencakup berbagai hal sebagi berikut :

a) Kompetensi invidu untuk menerima, menghormati dan membangun kerjasama dengan siapapun juga yang memiliki perbedaan-perbedaan dari dirinya. 
b) Kompetensi kultural merupakan hasil dari kesadaran atas pengetahuan dan "bias kultural" yang dimilikinya atau sebagai faktor yang mempengaruhi perbedaan kultur

c) Proses pengembangan komptensi kultural memerlukan pengembangan pengetahuan, ketrampilan, sikap dan perilaku yang memungkinkan seseorang memahami dan berinteraksi secara efisien dengan orang yang memiliki perbedaan kultur.

Pendidikan multikultural juga sangat relevan dengan pendidikan demokrasi di masyarakat plural seperti Indonesia, yang menekankan pada pemahaman akan multi etnis, multi ras, dan multikultur yang memerlukan konstruksi baru atas keadilan, kesetaraan dan masyarakat yang demoktratis.

\section{Siswa Yang Berkarakter}

Bila merujuk pada David Elkind \& Freddy Sweet (2004), seperti yang dikutip Samani pendidikan karakter dimaknai sebagai berikut: "Character education is the deliberate effort to belp people understand, care about, and act upon core ethical values. When we think about the kind of character we want for our children, it is clear that we want them to be able to judge what is right, care deeply about what is right, and then do what they believe to be right, even in the face of pressure from without and temptation from within". (Pendidikan karakter adalah usaha yang disengaja untuk membantu orang memahami, peduli, dan bertindak berdasarkan nilai etika inti. sementara itu Ristianti, D. H., Danim, S., Winarto, H., \& Dharmayana, I. W. (2019) menyimpulkan bahwa karakter siswa dapat dikembangkan melalui pelaksanaan bimbingan kelompok yang optimal dilaksanakan secara kontinyu. Ketika kita memikirkan jenis karakter yang kita inginkan untuk anak-anak kita, jelas bahwa kita ingin mereka dapat menilai apa yang benar, sangat peduli dengan apa yang benar, dan kemudian melakukan apa yang mereka yakini benar, bahkan di dalam menghadapi tekanan dari luar dan godaan dari dalam). Sejalan dengan definisi tersebut, pemerintah melalui Puskur (2010) memberi ciri-ciri pendidikan karakter sebagai berikut:

a) mengembangkan potensi kalbu/nurani/afektif peserta didik sebagai manusia dan warganegara yang memiliki nilai-nilai budaya dan karakter bangsa;

b) mengembangkan kebiasaan dan perilaku peserta didik yang terpuji dan sejalan dengan nilai-nilai universal dan tradisi budaya bangsa yang religius;

c) 3. menanamkan jiwa kepemimpinan dan tanggung jawab peserta didik sebagai generasi penerus bangsa;

d) mengembangkan kemampuan peserta didik menjadi manusia yang mandiri, kreatif, berwawasan kebangsaan; dan 
173 | TADBIR : Jurnal Studi Manajemen Pendidikan, Vol. 3, No. 2, November 2019

e) mengembangkan lingkungan kehidupan sekolah sebagai lingkungan belajar yang aman, jujur, penuh kreativitas dan persahabatan, serta dengan rasa kebangsaan yang tinggi dan penuh kekuatan (dignity).

Nilai dan Deskripsi Nilai Pendidikan Budaya dan Karakter Bangsa

\begin{tabular}{|c|c|}
\hline NILAI & DESKRIPSI \\
\hline 1. Religius & $\begin{array}{l}\text { Sikap dan perilaku yang patuh dalam melaksanakan } \\
\text { ajaran agama } \\
\text { yang dianutnya, toleran terhadap pelaksanaan ibadah }\end{array}$ \\
\hline 2. Jujur & $\begin{array}{l}\text { Perilaku yang didasarkan pada upaya menjadikan } \\
\text { dirinya sebagai } \\
\text { orang yang selalu dapat dipercaya dalam perkataan, }\end{array}$ \\
\hline 3. Toleransi & $\begin{array}{l}\text { Sikap dan tindakan yang menghargai perbedaan } \\
\text { agama, suku, etnis, }\end{array}$ \\
\hline 4. Disiplin & $\begin{array}{l}\text { Tindakan yang menunjukkan perilaku tertib dan } \\
\text { patuh pada berbagai }\end{array}$ \\
\hline 5. Kerja Keras & $\begin{array}{l}\text { Perilaku yang menunjukkan upaya sungguh-sungguh } \\
\text { dalam mengatasi } \\
\text { berbagai hambatan belajar dan tugas, serta }\end{array}$ \\
\hline 6. Kreatif & $\begin{array}{l}\text { Berpikir dan melakukan sesuatu untuk menghasilkan } \\
\text { cara atau hasil }\end{array}$ \\
\hline 7. Mandiri & $\begin{array}{l}\text { Sikap dan perilaku yang tidak mudah tergantung pada } \\
\text { orang lain }\end{array}$ \\
\hline 8. Demokratis & $\begin{array}{l}\text { Cara berfikir, bersikap, dan bertindak yang menilai } \\
\text { sama hak dan }\end{array}$ \\
\hline 9. Rasa Ingin Tahu & $\begin{array}{l}\text { Sikap dan tindakan yang selalu berupaya untuk } \\
\text { mengetahui lebih } \\
\text { mendalam dan meluas dari sesuatu yang }\end{array}$ \\
\hline $\begin{array}{l}\text { 10. Semangat } \\
\text { Kebangsaan }\end{array}$ & $\begin{array}{l}\text { Cara berpikir, bertindak, dan berwawasan yang } \\
\text { menempatkan } \\
\text { kepentingan bangsa dan negara di atas kepentingan }\end{array}$ \\
\hline 11. Cinta Tanah Air & $\begin{array}{l}\text { Cara berfikir, bersikap, dan berbuat yang menunjukkan } \\
\text { kesetiaan, } \\
\text { kepedulian, dan penghargaan yang tinggi terhadap }\end{array}$ \\
\hline $\begin{array}{l}\text { 12. Menghargai } \\
\text { Prestasi }\end{array}$ & $\begin{array}{l}\text { Sikap dan tindakan yang mendorong dirinya untuk } \\
\text { menghasilkan } \\
\text { sesuatu yang berguna bagi masyarakat, dan mengakui, }\end{array}$ \\
\hline
\end{tabular}

TADBIR : Jurnal Studi Manajemen Pendidikan vol. 3, no. 2, November 2019 IAIN Curup - Bengkulu | p-ISSN 2580-3581; e-ISSN 2580-5037 


\begin{tabular}{cl}
\hline $\begin{array}{c}\text { 13. Bersahabat/ } \\
\text { Komuniktif }\end{array}$ & $\begin{array}{l}\text { Tindakan yang memperlihatkan rasa senang } \\
\text { berbicara, bergaul, dan } \\
\text { bekeria sama dengan orang lain }\end{array}$ \\
\hline 14. Cinta Damai & $\begin{array}{l}\text { Sikap, perkataan, dan tindakan yang menyebabkan } \\
\text { orang lain merasa }\end{array}$ \\
\hline 15. Gemar Membaca & $\begin{array}{l}\text { Kebiasaan menyediakan waktu untuk membaca } \\
\text { berbagai bacaan yang }\end{array}$ \\
\hline 16. Peduli & $\begin{array}{l}\text { Sikap dan tindakan yang selalu berupaya mencegah } \\
\text { kerusakan pada } \\
\text { lingkungan }\end{array}$ \\
\hline 17. Peduli Sosial & $\begin{array}{l}\text { Sikap dan tindakan yang selalu ingin memberi bantuan } \\
\text { pada orang lain }\end{array}$ \\
\hline 18. Tanggung-jawab & $\begin{array}{l}\text { Sikap dan perilaku seseorang untuk melaksanakan } \\
\text { tugas dan } \\
\text { kewaibannya, yang seharusnya dia lakukan, terhadap } \\
\text { diri sendiri, masyarakat, lingkungan (alam, sosial dan }\end{array}$ \\
\hline
\end{tabular}

Catatan: Sekolah dan guru dapat menambah atau pun mengurangi nilainilai tersebut sesuai dengan kontek masing masing sekolah.

Pendidikan budaya dan karakter bangsa hendaknya direncanakan bersama oleh guru, kepala sekolah dan tenaga kependidikan di awal tahun/ semester dengan prinsip-prinsip sbb.: 1) berkelanjutan, 2) melalui semua pelajaran, muatan lokal, kepribadian dan budaya sekolah, 3) nilai tidak diajarkan tapi dikembangkan, 3) dilakukan oleh peserta didik secara aktif. Perencanaan itu harus tercermin dalam KTSP, silabus dan RPP, baik untuk kegiatan di dalam sekolah maupun di luar sekolah (Puskur (Pusat Kurikulum) Kemendiknas 2010).

Berdasarkan hasil penelitian Zuchdi (2010) bahwa model pendidikan karakter yang efektif sepatutnya dilakukan di sekolah-sekolah adalah yang menggunakan pendekatan komprehensif. Pembelajarannya tidak hanya melalui bidang studi tertentu, tetapi diintegrasikan ke dalam berbagai bidang studi. Metode dan strategi yang digunakan bervariasi yang sedapat mungkin mencakup inkulkasi (lawan indoktrinasi), keteladanan, fasilitasi nilai, dan pengembangan soft skills, Misalnya berpikir kritis, kreatif, berkomunikasi efektif, dan dapat mengatasi masalah (lihat juga Tan, 2011). Semua warga sekolah, pegawai administrasi, bahkan juga penjaga sekolah serta pengelola warung sekolah dan orang tua murid serta pemuka masyarakat perlu bekerja secara kolaboratif dalam melaksanakan program pendidikan karakter. Tempat pelaksanaan pendidikan karakter baik di dalam kelas maupun di luar kelas 
dalam berbagai kegiatan, termasuk kegiatan di rumah dan dalam lingkungan masyarakat dengan melibatkan partisipasi orang tua murid.

Paling tidak kembali kepada ajaran pendidikan karakter yang sejak awal ditanamkan oleh bapak Pendidikan Nasional Ki Hajar dewantoro yaitu Ing ngarso sung tulodo, ing madyo mbagun karso, tut wuri handayani. Bila dijelaskan secara singkat sebagai berikut:

Ing Ngarso Sung Tulodo : Dilihat dari asal katanya, maka ing ngarso sung tuladho itu berasal dari kata ing ngarso yang diartikan di depan, sung (lngsun) yang artinya saya, dan kata tulodo yang artinya tauladan. Dengan demikian arti dari semboyan ki Hajar Dewantara yang pertama ini adalah ketika menjadi pemimpin atau seorang guru harus dapat memberikan suri tauladan untuk semua orang yang ada disekitarnya.

Ing Madyo Mbangun Karso : Dari asal katanya, maka Ing Madyo Mbangun Karso berasal dari kata Ing Madyo yang diartikan di tengahtengah, Mbangun yang memiliki arti membangkitkan dan karso yang memiliki arti bentuk kemauan atau niat. Dengan demikian makna dari semboyan Ki Hajar Dewantara yang kedua ini adalah seorang guru di tengah-tengah kesibukannya diharapkan dapat membangkitkan semangat terhadap peserta didiknya.

Tut Wuri Handayani : Dari asal katanya, Tut Wuri Handayani, dirangkai dari kata tut wuri yang memiliki arti mengikuti dari belakang da kata handayani yang memilki arti memberikan motivasi atau dorongan semangat. Dengan demikian semboyan ki Hajar Dewantara yang ketiga ini memiliki makna bahwa seorang guru diharapkan dapat memberikan suatu dorongan moral dan semangat kepada peserta didik ketika guru tersebut berada di belakang.

\section{Penutup}

Kendati pendidikan agama, terutama pendidikan Agama Islam dilakasanakan dari jenjang sekolah dasar, menengah hingga perguruan tinggi, dalam pelaksanaanya masih terdapat banyak kendala masih perlu telaah ulang agar mampu mencapai tujuan pendidikan nasional sesuai dengan amanat UU Sisdiknas no 3/2003, melahirkan siswa yang bertaqwa kepada Tuhan yang Maha Esa dan berakhlak mulia. PAI yang masih bertumpu pada penguasaan materi (aspek kognisi), yang hanya diperlukan untuk menjawab soal-soal ujian, namun juga diikuti oleh pelaksanaan efektifitas penilaian karakter (Nuzuar, Fathurrochman, I., Amin, M., et al. 2017).

Kendala-kendala tersebut harus dicarikan jalan keluarnya, agar PAI tidak sekedar sebagai syarat pelengkap sebagaimana yang diamanatkan oleh UU, namun juga mampu melahirkan siswa yang benar-benar berkarakter sebagaimana yang tertera dalam indikasi siswa berkarakter oleh Puskur (2010). 
Salah satu jalan keluar, misalnya konten PAI lebih sederhana, yang menyangkut persoalan-persoalan riil di masyarakat, Masalah kedisiplinan, buang sampah di tempatnya, kewajiban menguasai ilmu pengetahuan dan teknologi, peduli terhadap yang lemah, menghargai perbedaan (toleransi). Memberi tauladan sebagaimana filosofi ing ngarso sing tulodo ing madyo mbangun karso tut wuri bandayani.

Pembelajarannya tidak hanya melalui bidang studi tertentu, tetapi diintegrasikan ke dalam berbagai bidang studi. Metode dan strategi yang digunakan bervariasi yang sedapat mungkin mencakup, keteladanan, fasilitasi nilai, dan pengembangan soft skills (antara lain berpikir kritis, kreatif, berkomunikasi efektif, dan dapat mengatasi masalah). Semua warga sekolah dan orang tua murid serta pemuka masyarakat perlu bekerja secara kolaboratif dalam melaksanakan program pendidikan karakter. Tempat pelaksanaan pendidikan karakter baik di dalam kelas maupun di luar kelas dalam berbagai kegiatan, termasuk kegiatan di rumah dan dalam lingkungan masyarakat dengan melibatkan partisipasi orang tua murid.

\section{Daftar Pustaka}

Abdullah, M Amin, 2004, “Agama dan (Dis) Integrasi Sosial: Tinjauan Materi dan Metodologi Pembelajaran Agama (Kalam dan Teologi) dalam Era Kemajemukan di Indonesia", Makalah disampaikan dalam Seminar Panitia Ad Hoc BPMPR RI Tentang Perubahan Kedua UUD 1945 dalam Perspektif Hukum, Sub Topik Agama dan Budaya, Mataram, 22 s.d. 23 Maret 2003

Al-Roubaie Amer, 2002, Globalization and the Muslim World, Shah Alam: Malita Jaya Publishing House.

Fathurrochman, I., \& Apriani, E. (2017). Pendidikan Karakter Prespektif Pendidikan Islam dalam Upaya Deradikalisasi Paham Radikal. Potensia: Jurnal Kependidikan Islam, 3(1), 122-142.

Iqbal, M. (2019). Apa Kabar Pembaharuan Pemikiran Islam? (Meneropong Pembaharuan Pemikiran Islam Post Cak Nur-Gus Dur). El-Afkar: Jurnal Pemikiran Keislaman dan Tafsir Hadis, 8(1), 25-38.

Mulkhan, Abdul Munir, 2004 "Kecerdasan Makrifat", dalam rangka pidato pengukuhan guru besar yang disampaikan dalam Rapat Senat Terbuka UIN Sunan Kalijaga pada tanggal 31 Maret 2004.

Mulkhan, Abdul Munir, 2005, Kesalehan Multikultural, Yogyakarta: PSAP Muhammadiyah, 2005

Nuzuar, Fathurrochman, I., Amin, M., et al. (2017). Manajemen dan Metodologi Pendidikan Agama Islam. Curup; LP2 IAIN Curup.

O’Neil, William F, 2008, Ideologi-Ideologi Pendidikan, Pustaka Pelajar Jogjakarta 
Puskur Kemendiknas, 2010, Pengembangan Budaya dan Pendidikan Karakter, Terdapat pada http:// sertifikasiguru.unm.ac.id/ diunduh tanggal 9 November 2012.

Rahardjo, M Dawam, 2015, "Liberalisme, Sekeluralisme dan Pluralisme”, dalam http://www.icrp-online.org, diakses pada 4 Mei 2015

Ramli, Murni, 2006, Pendidikan Moral di Jepang,http://murniramli.blogspot.com/, diunduh 8 Nov 2012

Ramli, Murni, 2009, Pendidikan Moral Orang Jepang, Terdapat pada http://murniramli. wordpress.com /2009/01/03/ pendidikan-moralorang-jepang/, diunduh 8 Nov 2012.

Ristianti, D. H., Danim, S., Winarto, H., \& Dharmayana, I. W. (2019). The Development Of Group Counselling Assessment Instruments. International Journal of Scientific \& Technology Research, 8(10), 267272. Retrieved from http://www.ijstr.org/paperreferences.php?ref=IJSTR-1019-23814

Samani, Muchlas, 2012. Konsep dan Model Pendidikan Karakter. Bandung: Remaja Rosada Karya.

Suaedi, Ahmad dkk, 2012, Islam dan Minoritas, The Wahid Institut, Jakarta

Suparlan, Parsudi "Menuju Masyarakat Indonesia yang Multikultural", Makalah, disajikan pada Simposium Internasional Jurnal Antropologi Indonesia ke3, Membangun Kembali "Indonesia yang Bhinneka Tunggal Ika" Menuju Masyarakat Multikultural, Universitas Udayana, Denpasar, Bali, 16-19 Juli 2002

Suseno, Franz Magnis, Memahami Hubungan Antar Agama di Indonesia, dalam Equality and Plurality dalam Konteks Hubungan antar Agama (Yogyakarta: Sukses Offset, 2008)

Sutrisno, Pembaharuan dan Pengembangan Pendidikan Islam (Yogyakarta: Fadilatama, 2011)

Suyatno, 2013, Multikulturalisme dalam Pendidikan Agama Islam: Problematika Pendidikan Agama Islam, di Sekolah, Jurnal ADDIN

Tan, Charlene, 2011, Islamic Education and Indoctrination, Routledge, New York

Wan Mohd. Nor Wan Daud, Filsafat dan Prektek Pendidikan Islam Syed Mubammad Naquib al-Attas (Bandung: Mizan,1998) hlm. 174.

Zamroni. 2011. Pendidikan Demokrasi pada Masyarakat Multikultural. Jakarta : Gavin Kalam Utama.

Zarkasyi, Hamid Fahmi, 2005, "Ghazwul Fikri: Gambaran Tentang Benturan Pandangan Hidup", Makalah pada Workshop Pemikiran Islam dan Barat, Pasuruan.

Zuchdi, Darmiyati, dkk. 2010, Pengembangan Model Pendidikan Karakter Terintegrasi dalam Pembelajaran Bidang Studi di Sekolah Dasar. Jurnal: Cakrawala Pendidikan, Mei 2010, Th. XXIX. 
This page belongs to the TADBIR : Jurnal Studi Manajemen Pendidikan

TADBIR : Jurnal Studi Manajemen Pendidikan vol. 3 , no. 2, November 2019 IAIN Curup - Bengkulu | p-ISSN 2580-3581; e-ISSN 2580-5037 